\title{
WEBSITE BLOCKING INJUNCTIONS TO PREVENT COPYRIGHT INFRINGEMENTS: PROPORTIONALITY AND EFFECTIVENESS
}

\author{
DAVID LINDSAY*
}

\section{INTRODUCTION}

The liability of internet intermediaries, particularly Internet Service Providers ('ISPs'), for the unlawful online actions of third party users is a persistent theme and problem of cyberlaw. ${ }^{1}$ The creation of an intermediary liability regime involves balancing the benefits intermediaries provide in facilitating access to internet content on the one hand, with the advantages of leveraging intermediary control over access on the other. ${ }^{2}$ Intermediaries are targets for attempts to control unlawful end-user activities as bringing actions against individual users is expensive, while regulating access via intermediaries is more cost-effective. ${ }^{3}$ Imposing liability on intermediaries can, however, have significant unwelcome effects, or 'collateral damage', especially on the rights to freedom of expression and privacy of end-users.

The most recent addition to intermediary liability law is the jurisdiction to award injunctions against intermediaries to block internet access in order to prevent online copyright infringements. In Australia, section 115A of the Copyright Act 1968 (Cth) ('the Australian Act'), which provides for injunctions against intermediaries that provide access to online locations outside Australia,

* $\quad$ Faculty of Law, Monash University. I am grateful for comments from three anonymous reviewers, which have resulted in improvements to the text.

1 See, eg, Jeremy de Beer and Christopher D Clemmer, 'Global Trends in Online Copyright Enforcement: A Non-neutral Role for Network Intermediaries' (2009) 49 Jurimetrics 375; Lilian Edwards, 'The Rise and Fall of Intermediary Liability Online' in Lilian Edwards and Charlotte Waelde (eds), Law and the Internet (Hart Publishing, $3^{\text {rd }}$ ed, 2009) 47; Jacqueline D Lipton, 'Law of the Intermediated Information Exchange' (2012) 64 Florida Law Review 1337; Jaani Riordan, The Liability of Internet Intermediaries (Oxford University Press, 2016).

2 See, eg, Matthew Schruers, 'The History and Economics of ISP Liability for Third Party Content' (2002) 88 Virginia Law Review 205; Douglas Lichtman and William Landes, 'Indirect Liability for Copyright Infringement: An Economic Perspective' (2003) 16 Harvard Journal of Law and Technology 395; Douglas Lichtman and Eric Posner, 'Holding Internet Service Providers Accountable' (2006) 14 Supreme Court Economic Review 221.

3 Jonathan Zittrain, 'Internet Points of Control' (2003) 44 Boston College of Law Review 653, 662. The economic argument in favour of imposing liability on an intermediary is that it is the 'least cost avoider': see Ronald J Mann and Seth R Belzley, 'The Promise of Internet Intermediary Liability' (2005) 47 William and Mary Law Review 239. 
came into effect from 27 June $2015 ;{ }^{4}$ and the first injunctions were awarded by Nicholas $\mathrm{J}$ of the Federal Court in December 2016. ${ }^{5}$ Since then, further orders have been made against the KickassTorrents $\operatorname{site}^{6}$ and an additional 66 infringing websites. ${ }^{7}$ The jurisdiction to award blocking injunctions was inspired by section 97A of the Copyright, Designs and Patents Act 1988 (UK) c 48 (the 'CDPA'), while the drafting was influenced by provisions of the Copyright Act (Singapore, cap 63) ('the Singaporean Act'), introduced in 2014. ${ }^{8}$

This article identifies and analyses the limits on the new statutory jurisdiction to grant no-fault injunctions. In particular, it examines the potential role of the proportionality principle, as applied under European Union ('EU') law, to set appropriate limits on the award of blocking orders. In this, the article is agnostic on the overall effectiveness of blocking injunctions. It is premature to form a judgment on whether targeted blocking, in isolation or as part of broader strategies, will have an impact on the level of online infringements. Instead, the article focuses on issues in interpreting and applying the jurisdiction, and particularly on establishing principled legal constraints on the discretion to award injunctions and on the form of blocking orders.

Blocking orders have been used, sometimes extensively, in jurisdictions including Austria, Belgium, Denmark, Finland, France, Italy, Ireland, and the United Kingdom ('UK'). ${ }^{9}$ Meanwhile, in Google Inc v Equustek Solutions Inc, ${ }^{10}$ in the absence of a specific statutory jurisdiction, the Canadian Supreme Court held that it had power, under its general equitable jurisdiction, to grant an injunction against Google, a non-party to the underlying action, to cease indexing or referencing search results that would provide access to a website involved in intellectual property infringements. While the growing use of injunctions against internet intermediaries provides the broader context for this article, and illustrates the dangers of an absence of principled limits on blocking and filtering, ${ }^{11}$ this article is more narrowly focused on the Australian statutory jurisdiction, and its immediate antecedents in the UK and Singapore. The analysis of the principles for limiting the award of blocking injunctions, however, has potentially broader application.

The article first reviews the main techniques for blocking internet access, and the benefits and costs of the techniques. Second, the article introduces the proportionality principle, as applied under EU and UK law, and identifies key

$4 \quad$ Copyright Amendment (Online Infringement) Act 2015 (Cth).

5 Roadshow Films Pty Ltd v Telstra Corporation Ltd (2016) 248 FCR 178 ('Roadshow [No 1]').

$6 \quad$ Universal Music Australia Pty Ltd v TPG Internet Pty Ltd [2017] FCA 435 ('Universal Music').

7 Roadshow Films Pty Ltd v Telstra Corporation Ltd [2017] FCA 965 ('Roadshow [No 2]'); Foxtel Management Pty Ltd v TPG Internet Pty Ltd [2017] FCA 1041.

8 Copyright Act (Singapore, cap 63) ss 193DDA, 193DDB, as inserted by the Copyright Amendment Act 2014 (Singapore).

9 See, eg, Althaf Marsoof, 'The Blocking Injunction - A Critical Review of Its Implementation in the United Kingdom within the Legal Framework of the European Union' (2015) 46 International Review of Intellectual Property and Competition Law (IIC) 632, 656; Universal Music [2017] FCA 435, [76] (Burley $\mathrm{J}$ ).

10 [2017] SCC 34.

11 See, eg, research conducted by the OpenNet Initiative: OpenNet Initative, Research $<$ https://opennet.net/ research>. 
controversies concerning the principle, which are subsequently examined in the context of blocking injunctions. Third, EU law relating to blocking injunctions is introduced and the role of proportionality in relevant rulings of the European Court of Justice ('ECJ') examined. Fourth, the implementation of EU law in the UK is explained, and the application of the proportionality principle to the award of blocking injunctions by UK courts is described and analysed. Fifth, the article describes and explains the Australian jurisdiction for awarding blocking injunctions, comparing this with the jurisdiction under the Singaporean Act, and emphasising the constraints on establishing jurisdiction and on the exercise of the discretion to award an injunction. Sixth, the article examines three issues that arise in the context of the proportionality of blocking injunctions: the application of 'rights-balancing' proportionality; the effectiveness of blocking orders; and the costs of blocking, including the allocation of costs between right holders and intermediary ISPs. The article concludes with a summary of the arguments, an assessment of the potential role for proportionality in establishing principled limits on the award of blocking injunctions, and the implications of the analysis for the exercise of the jurisdiction under section 115A.

\section{WEBSITE BLOCKING TECHNIQUES}

The following four main techniques may be used to block access to websites or other online locations. ${ }^{12}$

\section{A DNS Name Blocking}

The Domain Name System ('DNS') is a distributed database that matches a domain name to an Internet Protocol ('IP') address, which is a computer-readable address used for directing packets of data across the internet. ${ }^{13}$ The matching (or resolving) of domain names to IP addresses occurs on name servers operated by ISPs. DNS name blocking involves modifying or removing the DNS name server records so that a request for a domain name fails to resolve to an IP address. This can result in a domain name request returning either no response or being redirected to another site, such as a 'landing page' informing users that access has been blocked.

\section{B IP Address Blocking}

The IP address system operates by means of routers, operated by ISPs. The routers are responsible for detecting the IP address from the headers of data

12 This summary draws upon Office of Communications (UK), "'Site Blocking” to Reduce Online Copyright Infringement: A Review of Sections 17 and 18 of the Digital Economy Act' (Report, Secretary of State for Culture, Media and Sport, 27 May 2010) and Office of Communications (UK), 'OFCOM Report on Internet Safety Measures' (Report to Secretary of State for Culture, Media and Sport, 22 July 2014). See also Riordan, above n 1, 26-7 [2.01]-[2.06].

13 See, eg, David Lindsay, International Domain Name Law: ICANN and the UDRP (Hart Publishing, 2007) 6-7 [1.5]-[1.7]. 
packets and directing the packets across the internet. IP address blocking involves an ISP configuring its gateway routers so that the packets for a particular IP address are either blocked or redirected to another IP address.

\section{URL Site Blocking}

A Uniform Resource Locator ('URL') is the address of a specific file or document on the World Wide Web. The URL includes a domain name as well as the location of a file or document. URL blocking requires more scrutiny of data packets than name blocking or IP address blocking in order to determine the address of the file or document. It is usually implemented by an ISP re-routing traffic to a proxy server which has a 'blacklist' of blocked URLs. The requested URL is then compared with the blacklist and, if the requested URL matches a listed URL, the connection is refused or redirected to another site, such as a warning page. URL blocking entails packet inspection, which involves examining data other than a packet's header, and may involve either shallow packet inspection ('SPI') or deep packet inspection ('DPI'). ${ }^{14}$

\section{Hybrid Systems}

Hybrid blocking options involve a combination of the above techniques, and often implement a two stage approach. For example, IP address blocking can be used as a first stage to direct potentially blocked sites to a proxy server which then engages in packet inspection to block access to a specific URL. As explained later in this article, hybrid blocking is used in the UK.

Each of the above techniques has distinct costs and benefits.

DNS name blocking is relatively easy to circumvent. Circumvention can involve using a virtual private network ('VPN') which encrypts metadata (such as the domain name), using anonymity networks such as Tor (involving 'onion routing'), end-users entering an IP address rather than a domain name, or simply using an alternative DNS name server. ${ }^{15}$ Moreover, name blocking can lead to over-blocking in that a single domain name may be associated with multiple sites, some of which are involved with infringing content and some of which are not. On the other hand, unless an ISP implements measures to prevent or inhibit circumvention, name blocking is relatively inexpensive and straightforward to implement.

IP address blocking may also be relatively easily circumvented, such as by use of a VPN, use of anonymiser services and anonymity networks, or techniques such as 'fast fluxing' (high frequency rotation of IP addresses). ${ }^{16}$ IP address blocking is more likely to lead to over-blocking than other techniques as websites

14 See Ben Wagner, 'Deep Packet Inspection and Internet Censorship: International Convergence on an "Integrated Technology of Control”, (Paper, Global Voices, 23 June 2009) <https://advox.global voices.org/wp-content/uploads/2009/06/deeppacketinspectionandinternet-censorship2.pdf>.

15 See, eg, The Citizen Lab, University of Toronto, 'Everyone's Guide to By-passing Internet Censorship: For Citizens Worldwide' (Guide, September 2007) <https://citizenlab.ca/guides/everyones-guideenglish.pdf>.

16 See, eg, William Salusky and Robert Danford, 'Know Your Enemy: Fast-Flux Service Networks' (Paper, The Honeynet Project, 13 July 2007) <http://www.honeynet.org/papers/ff/>. 
commonly share a single IP address. While IP address blocking may entail costs, such as investment in additional network hardware and software, it is relatively easy to implement, unless it is accompanied by anti-circumvention measures.

URL site blocking may be circumvented by the use of VPNs, anonymising services, anonymity networks or rotation of IP addresses. URL blocking is more granular than DNS name blocking or IP address blocking, and so has lower levels of over-blocking. On the other hand, URL blocking is confined to web blocking, and does not extend to other internet applications. Moreover, as URL blocking requires capital expenditure, such as in deploying a proxy server, it is relatively expensive to implement effectively; and routing traffic via a proxy server may lead to degradation of network performance.

Some of the disadvantages of specific blocking techniques may be offset by hybrid systems, such as two-stage DNS name blocking and URL site blocking, which can reduce possible over-blocking. Nevertheless, establishing hybrid systems entails significant costs and, even then, the systems can be circumvented.

Evaluating blocking therefore involves assessing trade-offs associated with particular techniques. For example, DNS blocking is relatively inexpensive, but may be easily circumvented and, in the event of over-blocking, will impact the rights of third parties. URL blocking, on the other hand, is less susceptible to over-blocking but more expensive. The choice among techniques must take into account both the objectives of implementing blocking and criteria for evaluating the trade-offs.

\section{THE PROPORTIONALITY PRINCIPLE}

Proportionality is a fundamental principle of transnational, liberal constitutionalism; ${ }^{17}$ but is highly contested, applied in multiple legal contexts and has no single accepted meaning. ${ }^{18}$ While this article acknowledges these complexities, it argues that the proportionality principle can act as a principled constraint on blocking injunctions. Accepting that proportionality has different meanings in different legal regimes, ${ }^{19}$ this article applies the version of proportionality developed in the jurisprudence of the ECJ, as interpreted and implemented by UK courts. This form of proportionality is used as it is the version that been applied to constrain blocking orders under EU and UK law. Proportionality is relevant to the Australian jurisdiction since, as explained

17 Alec Stone Sweet and Jud Mathews, 'Proportionality Balancing and Global Constitutionalism' (2008) 47 Columbia Journal of Transnational Law 72.

18 See, eg, the collection of essays in Grant Huscroft, Bradley W Miller and Grégoire Webber (eds), Proportionality and the Rule of Law: Rights, Justification, Reasoning (Cambridge University Press, 2014); Tor-Inge Harbo, 'The Function of the Proportionality Principle in EU Law' (2010) 16 European Law Journal 158, 171-3.

19 See Dame Mary Arden, 'Proportionality: The Way Ahead?' [2013] Public Law 498; Wolf Sauter, 'Proportionality in EU Law: A Balancing Act?' (Discussion Paper No 2013-003, Tilburg Law and Economics Center, 25 January 2013) <http://ssrn.com/abstract=2208467>; R (Lumsdon) v Legal Services Board [2016] AC 697 ('Lumsdon'). 
below, ${ }^{20}$ it is an optional discretionary factor to be taken into account in awarding a blocking injunction.

The proportionality principle is designed to ensure that interferences with rights are justified as being no more than necessary to protect other rights or to achieve other legitimate goals. ${ }^{21}$ Under EU law, despite different formulations, the principle consists of the following three components: ${ }^{22}$

1. Suitability - 'whether the measure is suitable to achieve a legitimate aim';

2. Necessity - 'whether the measure is necessary to achieve that aim, namely, whether there are other less restrictive means capable of producing the same result'; and

3. Proportionality stricto sensu - 'even if there are no less restrictive means, it must be established that the measure does not have an excessive effect on the applicant's interests'.

Within these broad parameters, there is considerable flexibility in applying the principle to particular disputes. ${ }^{23}$ As the UK Supreme Court observed in Lumsdon:

any attempt to identify general principles risks conveying the impression that the court's approach is less nuanced and fact-sensitive than is actually the case. ... the way in which the principle of proportionality is applied in EU law depends to a significant extent upon the context. ${ }^{24}$

There are many controversies concerning the formulation and use of proportionality as a principle for limiting state power. This article takes up two main issues. First, proportionality operates both as a principle for balancing rights as against other rights (referred to in this article as 'rights-balancing') and as a standard for determining whether the means for pursuing a state objective is proportionate to the end (referred to as 'means/ends' analysis). ${ }^{25}$ In the context of blocking injunctions, 'rights-balancing' involves analysis of the effects of blocking access on the rights of all relevant parties, including intermediaries, website operators and internet users. 'Means/ends' analysis, on the other hand, involves evaluating blocking as a suitable (or proportionate) measure for reducing online copyright infringement, which necessarily entails considering the effectiveness and costs of blocking orders.

Secondly, in relation to 'rights-balancing', the article addresses claims that such an exercise is arbitrary and subjective. The classic objection was made by Habermas, in his critique of Alexy's constitutional theory, where he claimed that

20 See Part VI(B) below.

21 Aharon Barak, 'Proportionality and Principled Balancing' (2010) 4 Law \& Ethics of Human Rights 1.

22 Takis Tridimas, The General Principles of EU Law (Oxford University Press, $2^{\text {nd }}$ ed, 2006) 139.

23 Thus, proportionality has been referred to as a 'flexi-principle': $R$ (ProLife Alliance) $v$ British

Broadcasting Corporation [2004] 1 AC 185, 257 [138] (Walker LJ).

24 Lumsdon [2016] AC 697, 717 [23] (The Court).

25 For this distinction see: Julian Rivers, 'Proportionality and Variable Intensity of Review' (2006) 65 Cambridge Law Journal 174; Martin Luterán, 'The Lost Meaning of Proportionality' in Grant Huscroft, Bradley W Miller and Grégoire Webber (eds), Proportionality and the Rule of Law: Rights, Justification, Reasoning (Cambridge University Press, 2014) 21. 
'[b]ecause there are no rational standards for this, weighing takes place either arbitrarily or unreflectively, according to customary standards and hierarchies' ${ }^{26}$

On the other hand, those such as Alexy and Barak have variously argued that it is possible to establish a principled form of balancing that, for example, is capable of factoring in the intensity of an interference with rights, the degree of importance of reasons for justifying an interference and the calibration between rights, such that challenges of arbitrariness and subjectivity can be refuted. ${ }^{27}$

This article explains and analyses, in the context of website blocking injunctions: (1) how the two aspects of proportionality - 'rights-balancing' and 'means/ends' analysis - are applied; and (2) if there is a role for the courts to engage in a form of 'rights-balancing' in this context that escapes allegations of arbitrariness and subjectivity. The application of proportionality to blocking injunctions under EU and UK law is first explained, and the implications for the Australian regime subsequently examined.

\section{BLOCKING INJUNCTIONS UNDER EU LAW}

This Part of the article introduces EU law relating to blocking injunctions, then explains the application of proportionality analysis by the ECJ in the context of website blocking.

The first law to specifically provide for injunctions against internet intermediaries for third party copyright infringements was article 8(3) of the EU InfoSoc Directive. ${ }^{28}$ Article 8(3) provides that EU Member States must 'ensure that rightholders are in a position to apply for an injunction against intermediaries whose services are used by a third party to infringe a copyright or related right'.

The article must be read in the light of recital 59 to the Directive, which in part provides that:

without prejudice to any other sanctions and remedies available, rightholders should have the possibility of applying for an injunction against an intermediary who carries a third party's infringement of a protected work or other subjectmatter in a network. ... The conditions and modalities relating to such injunctions should be left to the national law of the Member States.

Apart from article 8(3), article 11 of the Enforcement Directive, ${ }^{29}$ which harmonises sanctions and remedies for all intellectual property rights, introduced a general requirement, in its third sentence, to provide for injunctions against

26 Jürgen Habermas, Between Facts and Norms: Contributions to a Discourse Theory of Law and Democracy (William Rehg trans, Polity Press, 1996) 259 [trans of: Faktizität und Geltung: Beiträge zur Diskurstheorie des Rechts und des demokratischen Rechtsstaats (first published 1992)].

27 See, eg, Robert Alexy, 'Constitutional Rights, Balancing, and Rationality' (2003) 16 Ratio Juris 131; Robert Alexy, 'The Construction of Constitutional Rights' (2010) 4 Law \& Ethics of Human Rights 19; Barak, above $\mathrm{n} 21$.

28 Directive 2001/29/EC of the European Parliament and of the Council of 22 May 2001 on the Harmonisation of Certain Aspects of Copyright and Related Rights in the Information Society [2001] OJ L 167/10 ('InfoSoc Directive'). See also Marsoof, above n 9, 634.

29 Directive 2004/48/EC of the European Parliament and of the Council of 29 April 2004 on the Enforcement of Intellectual Property Rights [2004] OJ L 157/5 (corrected version OJ L 195/16, 2 June 2004) ('Enforcement Directive'). 
intermediaries whose services are used to infringe intellectual property rights, while specifically providing that this requirement is 'without prejudice to article 8(3)' of the InfoSoc Directive. ${ }^{30}$ In L'Oréal SA v eBay International $A G,{ }^{31}$ a trade mark case which dealt with the interpretation of article 11 of the Enforcement Directive, the ECJ ruled on the scope of blocking injunctions, concluding that an injunction against an intermediary was not confined to preventing specific, identified infringements but extended to taking measures to prevent future infringements, provided certain limits were observed. Those limits include limitations arising from EU directives and from general principles of EU law, such as the proportionality principle..$^{32}$

Significantly, article 15(1) of the E-Commerce Directive ${ }^{33}$ provides that Member States must not impose a general obligation on intermediaries 'to monitor the information which they transmit or store, nor a general obligation actively to seek facts or circumstances indicating unlawful activity'. Recital 47 to that Directive further clarifies that the obligation not to monitor applies 'only with respect to obligations of a general nature; this does not concern monitoring obligations in a specific case and, in particular, does not affect orders by national authorities in accordance with national legislation'. Read with L'Oréal, this means that an injunction may require an intermediary to implement measures to prevent future infringements, but cannot extend to active, generalised monitoring.

The most important limits on blocking injunctions arise from the EU human rights framework. Under article 6 of the Treaty on the European Union ('TEU'), ${ }^{34}$ the EU human rights framework rests on three pillars: the EU Charter of Fundamental Rights ('Charter'); 35 the European Convention on Human Rights ('ECHR'); ${ }^{36}$ and the common constitutional traditions of the EU Member States. In its landmark ruling in Productores de Música de España (Promusicae) $v$ Telefónica de España SAU, ${ }^{37}$ the ECJ ruled that EU directives must be interpreted consistently with fundamental rights and other general principles of EU law, especially proportionality. The Court further held that the application of the proportionality principle requires that a 'fair balance' be struck between

30 See also article 2(2) of the Enforcement Directive, which states that the Directive is 'without prejudice' to specific provisions of the InfoSoc Directive, including article 8.

31 (C-324/9) [2011] ECR I-06011 ('L'Oréal').

32 Ibid I-6127 [144].

33 Directive 2000/31/EC of the European Parliament and of the Council of 8 June 2000 on Certain Legal Aspects of Information Society Services, in Particular Electronic Commerce, in the Internal Market [2000] OJ L 178/1 ('E-Commerce Directive').

34 Treaty on European Union, opened for signature 7 February 1992, [2010] OJ C 83/1 (entered into force 1 November 1993) ('TEU').

35 Charter of Fundamental Rights of the European Union [2010] OJ C 364/1 ('Charter').

36 Convention on the Protection of Human Rights and Fundamental Freedoms, opened for signature 4 November 1950, 213 UNTS 221 (entered into force 3 September 1953), as amended by Protocol No 14 bis to the Convention for the Protection of Human Rights and Fundamental Freedoms, opened for signature 27 May 2009, CETS No 204 (entered into force 1 September 2009) ('ECHR').

37 (C-275/6) [2008] ECR I-271 ('Promusicae'). See Fanny Coudert and Evi Werkers, 'In the Aftermath of the Promusicae Case: How to Strike the Balance?' (2010) 18 International Journal of Law and Information Technology 50. 
fundamental rights; in that case, between the right to intellectual property, on the one hand, and the rights to privacy and data privacy, on the other. ${ }^{38}$

The ECJ has ruled on the proportionality of blocking injunctions under article 8(3) in two important cases: Scarlet Extended SA v Société Belge des Auteurs, Compositeurs et Éditeurs SCRL (SABAM) ${ }^{39}$ and UPC Telekabel Wien GmbH v Constantin Film Verleih GmbH and Wega Filmproduktionsgesellschaft mbH. ${ }^{40}$

In Scarlet Extended, the ECJ was required to rule on an injunction under Belgian law imposing a general obligation on an ISP to identify copyright works and prevent infringements by filtering internet access. The Court held that such an injunction would be inconsistent with the prohibition on monitoring in article 15 of the E-Commerce Directive. More significantly, citing Promusicae, the ECJ applied the proportionality principle to assess whether such a broad obligation to filter established a 'fair balance' between copyright and other fundamental rights. First, the Court ruled that, especially due to the costs involved with establishing a filtering system, the obligation failed to strike a fair balance between the rights of the copyright holders and the ISP's freedom to conduct a business, guaranteed by article 16 of the Charter. Secondly, as the injunction required systematic monitoring of users, the ECJ held that it was a disproportionate interference with the right to protection of personal data under article 8 of the Charter. Thirdly, given that difficulties in distinguishing infringing from non-infringing content can result in over-blocking, the Court concluded that the injunction was a disproportionate interference with the freedom of internet users to receive and impart information, guaranteed by article 11 of the Charter.

While Scarlet Extended established that a general, unlimited filtering is disproportionate, this does not exclude more targeted blocking. In Telekabel, the ECJ addressed the proportionality of an injunction ordering an ISP to block access to an identified website $(<$ kino.to $>)$, where the order failed to specify the measures to be taken by the ISP. ${ }^{41}$ Although the Court ruled that this interfered with the ISP's freedom to conduct a business, the interference was proportionate in so far as it left the choice of measures to the ISP, provided that the ISP could establish that the measures taken were reasonable. In selecting the measures,

38 Xavier Groussot, 'Rock the KaZaA: Another Clash of Fundamental Rights' (2008) 45 Common Market Law Review 1745.

39 (C-70/10) [2011] ECR I-11959 ('Scarlet Extended'). See also, in relation to a hosting service provider, Belgische Vereniging van Auteurs, Componisten en Uitgevers CVBA (SABAM) v Netlog NV (European Court of Justice, C-360/10, 16 February 2012).

40 (European Court of Justice, C-314/12, 26 November 2013) ('Telekabel'). The issue also arose in Stichting Brein v Ziggo BV (European Court of Justice, C-610/15, 14 June 2017) ('Brein'), but as the ECJ held that the operators of The Pirate Bay torrent site infringed the public communication right, it did not need to consider the availability of a blocking injunction.

41 The Austrian court had issued an 'outcome prohibition' or Erfolgsverbot, which was an absolute bar on facilitating access to the infringing website without specifying the measures to be taken, which is a standard order under Austrian law: EMI Records Limited v British Sky Broadcasting Limited [2013] Bus LR 884, 908 [96] ('EMI Records'); Michael Williams and Rebecca Smith, 'Searching for the Silver Bullet: How Website Blocking Injunctions are Changing Online IP Enforcement' (2014) 25 Australian Intellectual Property Journal 59, 64-5; Christina Angelopoulos, 'Sketching the Outline of a Ghost: The Fair Balance between Copyright and Fundamental Rights in Intermediary Third Party Liability' (2015) 17(6) info 72, 75. 
however, the ECJ held that an injunction must be 'strictly targeted', so as to strike a balance between preventing third party infringements and protecting the freedom of information of internet users. ${ }^{42}$ Consequently, a targeted injunction is permissible, even where it does not lead to complete cessation of copyright infringements, provided the measures 'do not unnecessarily deprive internet users of the possibility of lawfully accessing the information' ${ }^{43}$ Most importantly, the Court applied a 'reasonable effectiveness' ${ }^{44}$ standard in applying 'means/ends' proportionality to conclude that an injunction can be effective even where it does not result in the complete cessation of copyright infringements, provided only that it makes access difficult or seriously discourages internet users from accessing the targeted site..$^{45}$

\section{A Blocking Injunctions and Proportionality under EU Law}

As a general principle of EU law, proportionality acts as a standard for assessing compliance of EU-level measures, and national implementation of EU measures, with the EU rights-based constitutional order. ${ }^{46}$

From Promusicae, it is clear that, in the context of protecting copyright, a 'fair balance' must be struck between copyright and other fundamental rights. Nevertheless, as pointed out by Geiger and Izyumenko, there is an inherent tension in the application of 'rights-balancing' proportionality in this context, arising from potentially inconsistent recitals to the InfoSoc Directive. ${ }^{47}$ Thus, while recital 9 requires harmonisation on the basis of a 'high level of protection' of copyright, recital 31 to the Directive, which refers to exceptions and limitations, requires a 'fair balance of rights and interests'.

Although Geiger and Izyumenko claim that in Telekabel the ECJ applied the objective of a 'high level' of protection to conclude that an injunction might be 'effective' even if relatively inefficient, it is not clear that this is the case. First, the relevant sections of Telekabel do not mention the objective of conferring a 'high level' of protection. Secondly, the ruling engages in an assessment (or 'balancing') of the relevant rights with no attempt at ranking the rights. On this point, the Court was concerned, above all, to refute the claim that an injunction can only be proportionate if it leads to a complete cessation of infringements. ${ }^{48}$ As blocking orders can always be circumvented, and as an injunction against one site cannot prevent infringing content from being available elsewhere, accepting an 'absolute effectiveness' standard would mean that an injunction could never be justified. The 'reasonable effectiveness' standard adopted in Telekabel was

42 Telekabel (European Court of Justice, C-314/12, 26 November 2013) [56].

43 Ibid [64].

44 Christophe Geiger and Elena Izyumenko, 'The Role of Human Rights in Copyright Enforcement Online: Elaborating a Legal Framework for Website Blocking' (2016) 32 American University International Law Review 43, 102.

45 Telekabel (European Court of Justice, C-314/12, 26 November 2013) [62]-[63].

$46 R v$ Minister for Agriculture, Fisheries and Food and the Secretary for Health, Ex parte: Fedesa (C331/88) [1990] ECR I-4023. See Harbo, above n 18.

47 Geiger and Izyumenko, above n 44, 106-8.

48 Telekabel (European Court of Justice, C-314/12, 26 November 2013) [58]-[61]. 
therefore the result of a pragmatic acceptance that 'absolute effectiveness' is impossible, together with the need to set a workable threshold provided there is some degree of effectiveness, and did not result from privileging copyright over other rights. Moreover, setting too high a threshold for effectiveness would de facto remove the jurisdiction to award blocking injunctions. ${ }^{49}$

Applying Promusicae, ECJ rulings addressing the proportionality of blocking injunctions have focused on whether there is a 'fair balance' as a form of 'rightsbalancing'. Although the 'rights-balancing' exercise has not been notably rigorous, there is no evidence that the Court has ranked copyright more highly than competing rights. In practice, the most difficult part of the balancing exercise has been the analysis of the effects of an order on an intermediary's freedom to conduct a business, guaranteed by article 16 of the Charter. In this, 'rights-balancing' bleeds over into 'means/ends' proportionality, as the impact on an ISP's business raises issues relating to the costs and effectiveness of blocking. It therefore seems that the focus of analysis inexorably shifts to 'means/ends' proportionality, and especially to issues relating to the effectiveness and costs of blocking orders. ${ }^{50}$ In the analysis of these issues, however, there are real questions as to the degree of deference to be given to the legislature's decision to introduce a jurisdiction to award blocking injunctions. If the jurisdiction is to be given effect, then injunctions must be available even though blocking may not be entirely effective. This leads to the need to set a threshold that is lower than absolute effectiveness which, in Telekabel, the ECJ set at making access difficult, or seriously discouraging internet users. Although not explicit from the ruling, a potential explanation for this relatively low threshold may be concerns relating to the competence of the court to adequately assess issues relating to the effectiveness of internet blocking.

The issues relating to the effectiveness and costs of intermediary blocking as part of the proportionality analysis have been explored in considerably more detail by UK courts determining applications for blocking injunctions, which are dealt with in the following section of this article.

\section{BLOCKING INJUNCTIONS IN THE UK}

Recital 59 to the InfoSoc Directive provides that conditions for the award of blocking injunctions are matters for national law, confirming that Member States have considerable discretion. In the UK, article 8(3) of the InfoSoc Directive was implemented in section 97A (and section 191JA in relation to performances) of the $C D P A$, introduced in 2003. ${ }^{51}$ This Part of the article examines the constraints on awarding blocking injunctions under UK law, focusing on the role of proportionality analysis.

\footnotetext{
49 See Stichting Brein v Ziggo BV (Opinion of Advocate General) (European Court of Justice, C-610/15, 8 February 2017), [83].

50 See, eg, ibid [78] ff.

51 Copyright and Related Rights Regulations 2003 (UK) SI 2003/2498, reg 27.
} 
The constraints on the UK jurisdiction arose due to the supremacy of EU law over UK law and the corresponding need for UK courts to apply EU law. Following the decision of the UK to leave the EU, EU law continues to be binding until the end of negotiations between the UK and the EU and, after that, the ongoing status of EU law is proposed to be dealt with by the 'Great Repeal Bill', ${ }^{52}$ which will convert EU law into domestic UK law. ${ }^{53}$ As relevant EU law, including ECJ rulings, will continue as part of UK law until (and if) it is amended, this article does not dwell on this issue. ${ }^{54}$ Moreover, as the article is concerned with whether proportionality is a suitable standard for limiting blocking orders, the conclusions are independent of the status of the EU principle in UK law.

Section 97A(1) of the CDPA confers jurisdiction on the High Court to grant an injunction against a service provider 'where that service provider has actual knowledge of another person using their service to infringe copyright'. The jurisdiction was surprisingly not exercised until the 2011 landmark judgment of Arnold $\mathrm{J}$ in Twentieth Century Fox Film Corporation $v$ British Telecommunications plc; ${ }^{55}$ but since then has developed rapidly so that the applicable principles are now settled, ${ }^{56}$ such that most applications are paperbased $^{57}$ and unopposed by respondent intermediaries. ${ }^{58}$

There are two stages in determining applications under section 97A: first, the court must decide if it has jurisdiction and, secondly, the court must exercise its discretion, guided by the proportionality principle, to determine whether an injunction is appropriate and, if so, to determine the terms of the injunction. ${ }^{59}$ This Part of the article deals briefly with jurisdiction, before focusing on the exercise of the Court's discretion.

52 The European Union (Withdrawal) Bill 2017 (UK) was introduced to the House of Commons on 13 July 2017.

53 In March 2017, following passage of the European Union (Notification of Withdrawal) Act 2017 (UK) c 9, the UK invoked article 50(2) of the TEU, initiating a two-year period of negotiation for withdrawing from the EU: see Letter from Theresa May to Donald Tusk, 29 March $2017<$ https://www.gov.uk/ government/uploads/system/uploads/attachment_data/file/604079/Prime_Ministers_letter_to_European_ Council_President_Donald_Tusk.pdf $>$.

54 For a general explanation of the implications of Brexit for intellectual property law, see: Richard Arnold, Lionel Bently, Estelle Derclaye and Graeme Dinwoodie, 'The Legal Consequences of Brexit through the Lens of IP Law' (Research Paper No 21, University of Cambridge Faculty of Law, February 2017) $<$ https://papers.ssrn.com/sol3/papers.cfm?abstract_id=2917219>.

55 Twentieth Century Fox Film Corporation v British Telecommunications PLC [2012] 1 All ER 806 ('Newzbin 2').

56 Paramount Home Entertainment International Ltd v British Sky Broadcasting Ltd [2014] ECDR 7, [2] (Arnold J).

57 Twentieth Century Fox Film Corporation v Sky UK Ltd [2015] EWHC (Ch) 1082, [7]-[15] (Birss J) ('Popcorn Time').

58 Paramount Home Entertainment International Ltd v British Sky Broadcasting Ltd [2014] EWHC (Ch) 937, [4] (Henderson J).

59 Ibid [12]-[13] (Henderson J); Popcorn Time [2015] EWHC (Ch) 1082, [25] (Birss J). 


\section{A Jurisdiction}

Under section 97A, four matters (or 'threshold conditions') must be made out for the court to have jurisdiction to award a blocking injunction. ${ }^{60}$ The four conditions are that: the respondent intermediary must be a 'service provider'; ${ }^{61}$ the users and/or operators of the target websites must infringe copyright; the users and/or operators of the target websites must use the respondent's services to infringe copyright; and the respondent must have actual knowledge of the infringements. While the last condition is not required by article 8(3) of the InfoSoc Directive, it seems to have been intended to reflect the obligation not to monitor under article 15 of the E-Commerce Directive, with Arnold J observing that '[i]f ISPs could be required to block websites without having actual knowledge of infringing activity, that would be tantamount to a general obligation to monitor'. ${ }^{62}$

A number of contentious issues have arisen in applying the four conditions, especially in their application to peer-to-peer services. ${ }^{63}$ In general, however, UK courts have adopted a generous approach to interpreting the conditions. For example, in Newzbin 2, in relation to the fourth condition, Arnold $\mathrm{J}$ held that it was sufficient to establish that a service provider has knowledge of one or more persons using its service to infringe copyright, and that it was not necessary to prove 'actual knowledge of a specific infringement of a specific work by a specific individual' ${ }^{64} \mathrm{He}$ further held that the knowledge requirement may be satisfied by sufficiently detailed notice with a 'reasonable opportunity to investigate the position'. ${ }^{65}$ As proportionality has not arisen in interpreting and applying the conditions for establishing jurisdiction, this article does not address these issues further, except to note the possible role for proportionality in interpreting statutory conditions for jurisdiction, which is taken up later in the article.

\section{B Discretion}

Under EU jurisprudence, in exercising the discretion to award an injunction, UK courts must apply the proportionality principle. In accordance with the principle in Marleasing SA v La Comercial Internacional de Alimentación, ${ }^{66}$ national implementations of EU directives must be interpreted consistently with EU law, including the proportionality principle. ${ }^{67}$ In addition, there are two

60 See, eg, Richard Arnold, 'Website-Blocking Injunctions: The Question of Legislative Basis' (2015) 37 European Intellectual Property Review 623.

61 A 'service provider' is defined in Electronic Commerce (EC Directive) Regulations 2002 (UK) SI 2001/2555, reg 2.

62 Cartier International AGv British Sky Broadcasting [2015] 1 All ER 949, 995 [141] ('Cartier').

63 See Riordan, above n 1, 50-2 [3.01]-[3.08].

64 Newzbin 2 [2012] 1 All ER 806, 852 [148].

65 Ibid [149].

66 (C-106/89) [1990] ECR I-4135.

67 See Cartier International AG v British Sky Broadcasting [2017] 1 All ER 700, 726 [68] (Kitchin LJ) ('Cartier Appeal'); Silke von Lewinski, 'Introduction' in Michael M Walter and Silke von Lewinski (eds), European Copyright Law: A Commentary (Oxford University Press, 2010) 3, 20-1 [1.0.38]. 
specific sources of EU law that require the application of proportionality to the exercise of the Court's discretion. First, article 8(1) of the InfoSoc Directive provides that any sanctions or remedies must be 'effective, proportionate and dissuasive'. ${ }^{68}$ Secondly, as explained above, in Promusicae the ECJ held that the proportionality principle must be applied to the interpretation of EU directives so as to strike a 'fair balance' between the respective rights.

The application of proportionality analysis to the award of blocking injunctions has been refined, and spelled out, in a series of judgments delivered by Arnold J. In examining the application of the principle, Arnold J's first instance judgment in Cartier, ${ }^{69}$ as confirmed by the judgment of the Court of Appeal, ${ }^{70}$ is especially important. As that case concerned orders to block access to trade mark infringing websites, which are not supported by the statutory jurisdiction in section 97A of the CDPA, it was contested by the ISPs. As a result, the case presented the opportunity for a more focused analysis of the issues relating to the proportionality of orders than standard section 97A cases.

In Cartier, Arnold $\mathrm{J}$ listed seven considerations as relevant to the proportionality of a blocking injunction, ${ }^{71}$ which were then approved by the Court of Appeal and formulated as follows:

(i) The comparative importance of the rights that were engaged and the justifications for interfering with those rights.

(ii) The availability of alternative measures which were less onerous.

(iii) The efficacy of the measures which the order required the ISPs to adopt, and in particular whether they would seriously discourage the ISPs' subscribers from accessing the target websites.

(iv) The costs associated with those measures, and in particular the costs of implementing the measures.

(v) The dissuasiveness of those measures.

(vi) The impact of those measures on lawful users of the internet.

(vii) The substitutability of other websites for the target websites..$^{72}$

While the first of the above factors addresses 'rights-balancing' proportionality, the remainder of the factors are relevant to 'means/ends' analysis, which has been given increasing prominence by UK courts. In fact, in Cartier, Arnold J went so far as to maintain that:

the key question on proportionality is whether the likely costs burden on the ISPs is justified by the likely efficacy of the blocking measures and the consequent benefit to [the rights holder] having regard to the alternative measures which are available to [the rights holder] and to the substitutability of the Target Websites. ${ }^{73}$

This emphasis on factors such as effectiveness and costs seems to confirm the conclusions reached by Rivers that British courts are more concerned with

68 Similarly, article 3(2) of the Enforcement Directive provides that remedies for infringements of intellectual property rights must be 'effective, proportionate and dissuasive': see Cartier [2015] 1 All ER 949, 1007 [184] (Arnold J).

69 Cartier [2015] 1 All ER 949.

70 Cartier Appeal [2017] 1 All ER 700.

71 Cartier [2015] 1 All ER 949, 1008 [189]-[190].

72 Cartier Appeal [2017] 1 All ER 700, 739 [127] (Kitchin LJ).

73 Cartier [2015] 1 All ER 949, 1021 [261]. 
proportionality as a principle for limiting state interference than as a principle for optimising rights. ${ }^{74}$

This does not mean, however, that 'rights-balancing' has been ignored by UK courts, as the exercise of the discretion invariably takes into account both aspects of proportionality. In the landmark Newzbin 2 judgment, for example, Arnold $\mathbf{J}$ concluded that the rights of the copyright owners outweighed the rights to freedom of expression (under article 10 of the ECHR) of users of an infringing website and, even more clearly, the operators of an infringing website. ${ }^{75}$ In considering the ISP's rights, however, Arnold J placed most weight on the cost of implementing the order, which he found to be 'modest and proportionate' ${ }^{76}$

The primacy given to 'means/ends' analysis under UK law, however, is clear from other judgments in the series delivered by Arnold J. For example, in EMI Records ${ }^{77}$ following a 'rights-balancing' exercise, Arnold J identified the two main considerations relating to the costs and benefits of a blocking order as, first, the effectiveness of the order and, secondly, the costs to the ISP of complying. On effectiveness, taking into account the possibility of users circumventing a block, Arnold $\mathrm{J}$ repeated what he had first said in Newzbin 2, that a blocking injunction might be proportionate even if it 'only prevents access by a minority of users' ${ }^{78}$ In relation to the costs of the order, Arnold $\mathrm{J}$ held that, as explained further below, compliance was not unduly burdensome as this involved the application of technical measures already available to the ISP. ${ }^{79}$

\section{Blocking Injunctions and Proportionality under UK Law}

In applying the proportionality principle in exercising the discretion to award a blocking injunction, UK courts have applied both 'rights-balancing' and 'means/ends' analyses. As might be expected from common law courts, the proportionality analysis has been more detailed and fact-intensive than in other EU jurisdictions and, by its nature, more so than in ECJ rulings.

Provided an injunction is sufficiently targeted, the 'rights-based' analysis has bordered on perfunctory. In the case of a website that hosts predominantly infringing content, the rights of the copyright owner invariably outweigh the rights to freedom of expression of both users and website operators, as the right to freedom of expression is not absolute and does not extend to a right to infringe. Should a targeted website host a significant amount of non-infringing material, however, the 'rights-based' analysis would entail a different balancing, in that freedom of expression would be a weightier consideration. To date, however, the most difficult 'rights-based' considerations before UK courts, as with the ECJ, have concerned an ISP's freedom to carry on business which, as explained above, necessarily bleeds into 'means/ends' analysis.

\footnotetext{
74 Rivers, above $\mathrm{n} 25,176$.

75 Newzbin 2 [2012] 1 All ER 806, 853 [200].

76 Ibid.

77 [2013] Bus LR 884.

78 Ibid 909 [104]; Newzbin 2 [2012] 1 All ER 806, [198].

79 EMI Records [2013] Bus LR 884, 909 [102]. This point had previously been made in Newzbin 2 [2012] 1 All ER 806, 862 [177].
} 
In Cartier, detailed evidence was led concerning the effectiveness and costs of blocking injunctions. In relation to effectiveness, Arnold J accepted evidence that section 97A injunctions had led to a 'marked and sustained drop in traffic' to the blocked websites. ${ }^{80}$ Against this, however, evidence was led concerning a report which had influenced the Court of Appeal of The Hague in Ziggo BV and XS4ALL v Stichting Bescherming Rechten Entertainment Industrie Nederland (Brein), ${ }^{81}$ to conclude that an order to block access to the The Pirate Bay website would not be proportionate, as blocking orders do not reduce the overall level of infringement. ${ }^{82}$ According to the report, blocking access had no impact on the overall percentage of Dutch users downloading from infringing sites. ${ }^{83}$

Apart from questioning the methodology employed in the study, Arnold $\mathrm{J}$ held that it was 'wrong in principle' to assess the effectiveness of a blocking order by reference to its effect on overall levels of infringement. ${ }^{84}$ In support of this conclusion, he applied the Telekabel 'effectiveness threshold' that, for an injunction to be effective, it must at least 'seriously discourage' users from accessing the blocked website. ${ }^{85}$ In this, the judgment is consistent with Arnold J's earlier test, that an injunction is sufficiently effective if it 'prevents access by a minority of users'. On appeal, Arnold J's conclusions in Cartier on effectiveness were supported by the Court of Appeal which, nevertheless, also supported Arnold J's statement that a blocking order might be less likely to be proportionate if there were a large number of alternative websites that provided access to the same infringing material..$^{86}$

In relation to costs, in the award of section $97 \mathrm{~A}$ orders it has become generally accepted that ISPs bear the costs of implementing the orders, but rights holders bear the costs of monitoring target websites and notifying ISPs of any change, such as a new web address. ${ }^{87}$ As Cartier involved an extension beyond section 97A, Arnold J undertook a comprehensive analysis of the costs of UK ISPs implementing blocking orders. In the UK, the costs of blocking websites occur in a very specific context, as ISPs have put in place arrangements to comply with the voluntary regime for blocking access to offensive and unlawful content administered by the Internet Watch Foundation ('IWF'), ${ }^{88}$ and with other parental control measures, as well as section 97A orders. For example, in 2004 British Telecommunications ('BT') introduced a two-stage (or 'hybrid') blocking system, known as Cleanfeed, involving a combination of IP address re-routing to

\footnotetext{
80 Cartier [2015] 1 All ER 949, 1013 [222].

81 Gerechtshof Den Haag (Court of Appeal of The Hague), No 200.105.418/01, 28 January 2014.

82 Cartier [2015] 1 All ER 949, 1002 [167].

83 Joost Poort et al, 'Baywatch: Two Approaches to Measure the Effects to Blocking Access to The Pirate Bay’ (2014) 38 Telecommunications Policy 383.

84 Cartier [2015] 1 All ER 949, 1005 [173].

85 Ibid 1005 [174]-[175].

86 Cartier Appeal [2017] 1 All ER 700, 737 [118] (Kitchin LJ).

87 Cartier [2015] 1 All ER 949, 1016-17 [239].

88 The IWF system operates by means of a dynamically updated blacklist of URLs: see Emily B Laidlaw, 'The Responsibilities of Free Speech Regulators: An Analysis of the Internet Watch Foundation' (2012) 20 International Journal of Law and Information Technology 312.
} 
a proxy server which then engages in URL blocking. ${ }^{89}$ Subsequently, in 2012 BT introduced a system called Nominum, which involves DNS address blocking; and it currently implements section 97A orders by using both Cleanfeed and Nominum..$^{90}$

In Cartier, Arnold $\mathrm{J}$ took into account the extent to which the ISPs had already invested in blocking infrastructure, to conclude that the marginal cost of implementing a single order is relatively small. ${ }^{91}$ That said, he considered that the Court should take into account the cumulative costs of implementing orders which, given uncertainty about the scale of applications, might be difficult to predict. Nevertheless, taking into account that the implementation costs were small relative to the ISPs' total operating costs, and that they were likely to be passed on to subscribers, Arnold J concluded that, while costs are an important factor in the proportionality analysis, they were not such as to justify refusing an order. ${ }^{92}$

As contended above in relation to the ECJ rulings, the assessment by the courts of the effectiveness of injunctions has been conditioned by the need to give some effect to the decision of the legislature to provide for blocking injunctions. In Cartier, Arnold $\mathrm{J}$ made this imperative explicit: after observing that the jurisdiction was established on the basis of a policy decision that it was more efficient to impose an obligation on intermediaries than to require right holders to pursue end-users, he specifically concluded that:

Whether that is correct as a matter of economics is not for me to judge. Nor is it for me to judge whether it is good policy in other ways. That judgment has already been made by the legislators when they adopted art 8(3) of Information Society Directive and art 11 of the Enforcement Directive ...93

The policy assumptions underpinning the imposition of an obligation on intermediaries were taken up by the Court of Appeal in Cartier International $A G v$ British Sky Broadcasting ${ }^{94}$ in their consideration of who should bear compliance costs, an issue that split the Court. The majority (consisting of Jackson and Kitchin LJJ) upheld Arnold J's conclusion that compliance costs should be borne by the ISPs. In reaching this conclusion, in relation to the contentious cumulative costs, the majority supported Arnold J's analysis that the ISPs should bear the costs as, first, the EU legislators had determined it was more efficient to impose a burden on ISPs and, secondly, that ISPs could pass the costs on to their subscribers. ${ }^{95}$ Moreover, the majority agreed with Arnold $\mathrm{J}$ that, as the intermediaries made a profit from services supplying access to infringing websites, the implementation costs were part of the costs of doing business. ${ }^{96}$ Against this, Briggs LJ concluded that implementation costs (as opposed to

89 Twentieth Century Fox Film Corporation v British Telecommunications plc [No 2] [2012] 1 All ER 869, 872 [6] (Arnold J).

90 Cartier [2015] 1 All ER 949, 967-8 [42]-[44] (Arnold J).

91 Ibid 1017 [241].

92 Ibid 1020 [253].

93 Ibid 1019 [251].

94 [2017] 1 All ER 700.

95 Cartier Appeal [2017] 1 All ER 700, 740-4 [132]-[150] (Kitchin LJ).

96 Cartier Appeal [2017] 1 All ER 700, 734 [143] (Kitchin LJ). 
capital costs) should be borne by the rights holders primarily on the basis that costs reasonably incurred by an innocent third party under an equitable duty to assist a rights holder should be recoverable..$^{97}$

The above analysis has explained the importance of proportionality under EU and UK law in conditioning the exercise of the jurisdiction to award blocking injunctions. It has also suggested some weaknesses of the application of proportionality by the courts, as well as indicating how the focus of the analysis has shifted to 'means/ends' concerns relating to the effectiveness and costs of orders. The next section of the article explains the different process that applies in determining the award of blocking injunctions in Australia and Singapore.

\section{BLOCKING INJUNCTIONS IN AUSTRALIA AND SINGAPORE}

The Australian website blocking regime was introduced in the shadow of the failure of graduated response. Following the High Court's decision in Roadshow Films Pty Ltd $v$ iiNet Ltd ${ }^{98}$ effectively holding that under Australian law an ISP that did no more than provide access to the internet could not be liable for the infringements of end-user subscribers, a convoluted policy debate resulted in the introduction of section 115A of the Copyright Act 1968 (Cth), which came into effect in June 2015.

The drafting of section 115A was influenced by corresponding provisions in the Singaporean Act, ${ }^{99}$ which are therefore referred to in this Part of the article for the purpose of comparison. There are more similarities between the Australian and Singaporean provisions than with section 97A of the $C D P A$, as the UK provision was drafted on the understanding it would be constrained by principles of EU law, including the proportionality principle.

This Part of the article gives more emphasis to the conditions for establishing jurisdiction under the Australian and Singaporean provisions than was given to jurisdiction under the UK $C D P A$, as they may operate as more important constraints on the award of injunctions than the conditions under UK law. The section then proceeds to explain the statutory constraints on the exercise of the discretion to award a blocking injunction under the Australian and Singaporean laws, before turning to an analysis of the application of the jurisdiction by courts determining applications for blocking orders. This analysis focuses on the judgments on the first two section 115A applications, Roadshow [No 1] and Universal Music as, based on the UK experience, it is likely there will be more substantial analysis in the early judgments interpreting the jurisdiction. Finally, this Part compares and contrasts the constraints established under the Australian jurisdiction with analogous constraints under the Singaporean Act.

97 Ibid 754-5 [200]-[204].

98 (2012) 248 CLR 42 ('iiNet').

99 Copyright Act (Singapore, cap 63) ss 193DDA, 193DDB. 


\section{A Jurisdiction}

Section 115A(1) of the Australian Act provides for the Federal Court, on application by the copyright owner, to award an injunction where it is satisfied of the following three cumulative conditions:

(a) a carriage service provider provides access to an online location outside Australia; and

(b) the online location infringes, or facilitates an infringement of, the copyright; and

(c) the primary purpose of the online location is to infringe, or to facilitate the infringement of, copyright (whether or not in Australia).

The conditions for jurisdiction under section 115A may be compared with those under the Singaporean Act, which in section 193DDA(1) establishes the following two cumulative conditions for awarding an injunction against a network service provider:

(a) the services of the network service provider have been or are being used to access an online location ... to commit or facilitate infringement of copyright in that material; and

(b) the online location is a flagrantly infringing online location ...

Like the Singaporean provision, section 115A applies where a service provider provides access to an 'online location', but unlike the UK and Singaporean provisions, under the Australian provision the online location must be outside Australia. The term 'online location' is deliberately not defined, being designed to apply not only to websites but to future technologies. ${ }^{100}$ The Australian provision is confined to preventing access to offshore locations as it is possible to bring an action directly against the host of a website located in Australia, ${ }^{101}$ but more difficult to bring an action against a site hosted offshore. As explained further below, the limitation to offshore locations may give rise to problems where users access content via a proxy website that is located in Australia.

A key problem with blocking injunctions is determining whether a website should be blocked, given that popular websites, such as YouTube, host both noninfringing and infringing content. Section 193DDA(1) of the Singaporean Act limits the locations in relation to which an injunction may be granted to those that are 'flagrantly infringing'. Section 193DDA(2) sets out a non-exhaustive list of factors to be taken into account in determining whether a location is 'flagrantly infringing', including: 'whether the primary purpose of the location is to commit or facilitate infringement'; 'whether the online location makes available or contains directories, indexes or categories of the means to commit or facilitate infringement'; and 'whether the location contains guides or instructions to circumvent measures ... that disable access'.

100 Revised Explanatory Memorandum, Copyright Amendment (Online Infringement) Bill 2015 (Cth), 8 [36] ('REM').

101 See, eg, Cooper v Universal Music Australia Pty Ltd (2006) 156 FCR 380. See also Roadshow [No 1] (2016) 248 FCR 178, 188 [38] (Nicholas J). 
The equivalent limitation under the Australian provision is the condition requiring that the primary purpose of the online location must be to infringe, or facilitate infringement. The Revised Explanatory Memorandum ('REM') to the Bill that introduced section $115 \mathrm{~A}$ indicated that the primary purpose test set an 'intentionally high threshold' explaining that, for example, the test 'would prevent an injunction to disable access to an art gallery website operated outside of Australia that may contain an unauthorised photograph'. ${ }^{102}$ There is clearly a relationship between the primary purpose test and the identification of the online location: the more narrowly the location is identified, such as if it is confined to part of a website (such as a URL), the more easily it may be to satisfy the test. While the 'flagrantly infringing' test in the Singaporean Act is more precise, with the factors set out in section 193DDA(2) providing greater guidance, it seems likely that at least some of the factors set out in the Singaporean Act would be taken into account under the Australian Act in determining the primary purpose of a location.

\section{B Discretion}

While the exercise of the discretion to award an injunction under section 97A of the CDPA is constrained by EU law, under the Australian and Singaporean provisions, which still require a balancing exercise, the discretion is limited solely by statutory factors.

A long list of non-exhaustive discretionary factors is set out in section $115 \mathrm{~A}(5)$ of the Australian Act, which includes factors that are relevant to determining whether a website is 'flagrantly infringing' under the Singaporean Act, such as: the flagrancy of the infringement; whether the online location makes available or contains directories, indexes or categories of the means to infringe copyright; whether the owner or operator of the online location demonstrates a disregard for copyright generally; and whether access to the online location has been disabled by orders from any court of another country on the ground of copyright infringement. As these factors are taken into account in determining jurisdiction under the Singaporean Act but in the exercise of the court's discretion under the Australian Act, jurisdiction may be more easily established in Australia than in Singapore.

In addition to the factors that mirror those relating to jurisdiction under the Singaporean Act, section 115A(5) includes the following two broad discretionary factors:

- 'whether disabling access to the online location is a proportionate response in the circumstances'; ${ }^{103}$ and

- 'whether it is in the public interest to disable access to the online location'. ${ }^{104}$

102 Roadshow [No 1] (2016) 248 FCR 178, 188 [38] (Nicholas J); Revised Explanatory Memorandum, Copyright Amendment (Online Infringement) Bill 2015 (Cth), 8 [6].

103 Copyright Act 1968 (Cth) s 115A(5)(e).

104 Copyright Act 1968 (Cth) s 115A(5)(g). 
These two factors are effectively surrogates for the kind of proportionality analysis applied under EU and UK law, and create the potential for the court to engage in 'rights-balancing'. For example, in relation to the public interest factor, the REM indicates that this would entail the court 'taking into account the public interest in freedom of expression, and other public interest issues such as, for example, freedom of access to information' ${ }^{105}$ While the REM states that the 'factors to be taken into account set an intentionally high threshold', ${ }^{106}$ the openended laundry list of factors confers a high level of discretion on the court. Moreover, the absence of clear jurisprudential constraints on considerations such as proportionality and public interest, such as those that apply to the proportionality principle under EU law, reinforce the highly discretionary nature of the Australian jurisdiction.

The factors to be taken into account in the exercise of the court's discretion under the Singaporean Act are quite different to the factors listed in the Australian Act, and include:

- 'the harm that has been or may foreseeably be caused to the plaintiff'; ${ }^{107}$

- 'the burden that the making of the order will place on the network service provider'; ${ }^{108}$

- 'the effectiveness of the order'; ${ }^{109}$

- 'any possible adverse effect on the business or operations of the network service provider'; ${ }^{110}$ and

- 'whether some other comparatively effective order would be less burdensome'. ${ }^{111}$

Although the list is open-ended, the factors focus exclusively on 'means/ends' considerations and fail to include any express factors relevant to 'rights-balancing'. Purely by reference to the statutory factors, then, it seems that 'rights-balancing' is less likely to occur under the Singaporean law and that, while open to an Australian court to engage in such an exercise, there is no clear jurisprudential framework for the analysis.

\section{Section 115A in Practice: Roadshow [No 1] and Universal Music}

The first two section 115A applications dealt with in Roadshow [No 1] were directed at carefully selected websites, with a view to their precedential value. The first application was made in relation to the SolarMovie websites (such as $<$ solarmovie.com>), from which a large number of films and television series were available, including by means of a search facility. The second application concerned claims for copyright infringements of television programs, such as

105 Revised Explanatory Memorandum, Copyright Amendment (Online Infringement) Bill 2015 (Cth), 5 [55].

106 Ibid 2 [6].

107 Copyright Act (Singapore, cap 63) s 193DB(3)(a).

108 Copyright Act (Singapore, cap 63) s 193DB(3)(b).

109 Copyright Act (Singapore, cap 63) s 193DB(3)(d).

110 Copyright Act (Singapore, cap 63) s 193DB(3)(e).

111 Copyright Act (Singapore, cap 63) s 193DB(3)(f). 
Wentworth, by means of well-known torrent sites, such as <thepiratebay.se $>$. Subsequently, Universal Music addressed an application to block access to the KickassTorrents website, which could be accessed via a number of different domain names.

The judgment of Nicholas J, granting the applications in Roadshow [No 1], identified a number of difficulties with the drafting of section 115A. For example, the limitation of the Australian provision to orders blocking access to locations 'outside Australia' may give rise to problems where access is effected by means of a proxy located in Australia. This may occur where reverse proxies are used as part of a Content Delivery Network ('CDN'), whereby client requests are directed to local servers that are part of a global network of proxies run by CDN operators, such as Akamai, Amazon or Cloudfare. ${ }^{112}$ While the issue did not need to be addressed in the applications before the Court, the widespread use of CDNs means that the issue may need to be resolved in future applications. Further problems arise from the drafting of the three conditions for jurisdiction in section $115 \mathrm{~A}(1)$, which are each expressed in the present tense, creating difficulties where, for instance, a website is temporarily taken offline prior to the award of an injunction. While the judgment exposes shortcomings with the drafting of section $115 \mathrm{~A}$, the sections of the judgment dealing with the discretion to award an injunction are potentially more important.

On this, given that the target websites were all used for 'industrial scale' infringements, the reasoning on the application of the section $115 \mathrm{~A}(5)$ discretionary factors was surprisingly succinct. The most important factors referred to by Nicholas $\mathrm{J}$ in Roadshow [No 1] were: the flagrancy of the infringement; ${ }^{113}$ that the operators of the target websites had shown a blatant disregard for copyright; ${ }^{114}$ and that blocking orders had been made by the courts of another country. ${ }^{115}$ While the target websites in that case were selected by the applicants so that the requirements of section $115 \mathrm{~A}$ would be easily satisfied, given that this was the first judgment to consider the provision, the lack of attention to the interpretation of the discretionary factors, including the potentially important considerations of proportionality and public interest, is disappointing.

Similarly, in Universal Music, Burley J also emphasised the flagrancy of the infringement, the disregard of the operators for copyright and the award of blocking orders in other jurisdictions. ${ }^{116}$ In relation to proportionality, Burley $\mathrm{J}$ accepted a submission that the orders needed to be 'effective at preventing a meaningful proportion of Australian users from infringing copyright via the online location in the future, without giving rise to a danger of "overblocking"

112 See Delarno Delvix, 'How CDN and International Servers Networking Facilitate Globalization', The Huffington Post (online), 9 June $2016<\mathrm{http}$ //www.huffingtonpost.com/entry/how-cdn-and-internationalservers-networking-facilitate_us_57cf4ed0e4b0eb9a57b68b9c >; Rob Frieden, 'Déjà Vu All Over Again: Questions and a Few Suggestions on How the FCC Can Lawfully Regulate Internet Access' (2015) 67 Federal Communications Law Journal 325.

113 Copyright Act 1968 (Cth) s 115A(5)(a).

114 Copyright Act (Singapore, cap 63) s 115A(5)(c).

115 Copyright Act (Singapore, cap 63) s 115A(5)(d).

116 Universal Music [2017] FCA 435 [76]. 
legitimate websites'. ${ }^{117}$ While this might be broadly comparable to the Telekabel threshold that an injunction must 'seriously discourage' users from accessing the blocked site, it seems more stringent than Arnold J's test, that an injunction is sufficiently effective if it 'prevents access to a minority of users'. Nevertheless, Burley J's analysis of the proportionality of the order appears compromised by some confusion between DNS name blocking and URL site blocking, ${ }^{118}$ based on an apparent conflation between a domain name and a URL. ${ }^{119}$

In contrast to the reasoning on the discretionary factors, the judgments in Roadshow [No 1] and Universal Music gave significantly more attention to the question of who should bear the costs of implementing an order, which was the most contentious issue between the parties. As explained above, in Cartier Appeal, the majority of the Court of Appeal upheld Arnold J's conclusion that both capital and compliance costs should be borne by the ISPs. In Roadshow [No 1], Nicholas J rejected Telstra's claim that the applicant copyright owners should bear the costs of establishing a system for implementing blocking as, referring to Arnold J's judgment on costs in Newzbin 2, the introduction of 115A made it essential for ISPs to have the technical capacity to implement blocking injunctions which, therefore, was no more than a general 'cost of carrying on business' ${ }^{120}$ Contrary to the conclusions reached by the UK courts, however, Nicholas $\mathrm{J}$ held that the right holders should be required to bear either all, or a significant proportion of, the compliance costs. ${ }^{121}$ In this, Nicholas J differed from the UK courts in that he accepted an analogy with liability for costs for implementing orders for preliminary discovery, known as Norwich Pharmacal orders, ${ }^{122}$ which are applications to discover the identity of online users from nonfault third parties. Moreover, unlike the UK courts, Nicholas J rejected the proposition that ISPs obtained a commercial advantage from providing access to target websites. ${ }^{123}$ In Universal Music, Burley J essentially endorsed Nicholas J's reasoning, holding that while ISPs should bear the costs of setting up a blocking system, the copyright owners should bear the compliance costs, largely by analogy with Norwich Pharmacal orders, by reference to a notional cost per blocked domain name. ${ }^{124}$

\section{Constraints on Blocking Injunctions: Comparing Australia and Singapore}

The constraints on awarding a blocking order under Australian and Singaporean law are necessarily set by the statutory conditions for determining the jurisdiction and by the reasoning process in applying the statutory discretionary factors.

117 Ibid [77] (emphasis in original).

118 Ibid [78].

119 Ibid [64].

120 Roadshow [No 1] (2016) 248 FCR 178, 208 [144].

121 Ibid 209 [147].

122 Norwich Pharmacal Co v Customs and Excise Commissioners [1974] 1 AC 133.

123 Roadshow [No 1] (2016) 248 FCR 178, 209 [147].

124 Universal Music [2017] FCA 435, [101], [105]. 
The main limitation on jurisdiction under the Australian Act is the requirement for the primary purpose of the online location to be to infringe or facilitate infringements, while the equivalent condition in the Singaporean Act requires that the location be 'flagrantly infringing'. Although section $115 \mathrm{~A}$ is confined to injunctions preventing access to a location outside Australia, the list of factors set out in the Singaporean Act for determining whether a site is flagrantly infringing suggests it is more difficult for jurisdiction to be established in Singapore than in Australia.

This interpretation of the Australian provision is confirmed by the inclusion, in section $115 \mathrm{~A}(5)$, of factors relevant to whether a site is 'flagrantly infringing' under the Singaporean Act as factors to be taken into account in exercising the court's discretion under the Australian Act. The long list of discretionary factors in the Australian Act has the effect of conferring considerable discretion on the Federal Court, and seems broader than the discretion under the Singaporean Act, where the listed factors are confined mainly to considerations relating to the effectiveness and costs of an order.

As is clear from the judgments in Roadshow [No 1] and Universal Music, there are unresolved problems with the drafting of section 115A. These include difficulties in determining the primary purpose of a 'location' and whether access may be blocked to proxies located in Australia. While these issues may need to be worked through in future applications, for the purposes of this article, it is important to note that it appears easier for jurisdiction to be established under the Australian provision than under the Singaporean Act and, once jurisdiction is established, the Federal Court would seem to have more discretion than courts in either the UK or Singapore.

\section{WHAT SHOULD THE CONSTRAINTS BE?}

Mandating internet access blocking is perilous. While there is the everpresent threat of over-blocking, there are systemic problems that arise from requiring intermediaries to establish an infrastructure for controlling access, with potential for scope creep, such as creeping censorship, and the prospect of increasing fragmentation of the internet into territorial jurisdictions. ${ }^{125}$ It is important, therefore, that laws mandating blocking are carefully targeted and confined. This Part of the article analyses the constraints that may be imposed on the award of blocking injunctions in relation to three of the most controversial issues that arise in the exercise of the jurisdiction: the role of 'rights-balancing'; the effectiveness of blocking orders; and the costs of implementing orders. As explained, the proportionality principle is relevant to the analysis of each of these issues.

125 Douwe Korff and Ian Brown, 'Social Media and Human Rights' (Issue Discussion Paper No 8, Council of Europe Commissioner for Human Rights, February 2012) 8. 


\section{A 'Rights-Balancing' and Blocking Injunctions}

As any form of internet blocking restricts communication and access to information it necessarily restricts rights. ${ }^{126}$ If rights are to be protected in a jurisdiction that provides for blocking, it is essential that the circumstances in which an interference with rights may be justifiable are clearly and transparently defined. Nevertheless, as explained in Part III, in applying 'rights-balancing' as part of the proportionality principle, problems have arisen concerning the relationship between 'rights-balancing' and 'means/ends' analysis, and in the extent to which 'rights-balancing' is susceptible to charges of arbitrary or subjective reasoning.

In the online context, conflicts between copyright and the rights to freedom of expression and privacy are more acute than offline. ${ }^{127}$ For example, taking down internet content, or blocking access, in response to copyright claims engages the rights of copyright owners, the freedom to communicate or disseminate content, and the rights of users to access content. ${ }^{128}$ If the respective rights are to be protected, and taken into account, there is no alternative but that some form of balancing is required. Questions then arise as to which body should be responsible for the balancing - the legislature or courts - and how the balancing exercise should be undertaken. Given the dangers of arbitrariness and subjectivity, there is a good case for a degree of deference to legislative decisionmaking. Nevertheless, if rights are to be protected, this cannot be left entirely to the vagaries of the legislative processes, where rights are often secondary to compromises entailed in enacting laws. A persistent danger with a legal system characterised by weak judicial oversight, such as Australian law, is that acknowledgement of rights as part of the legislative process is commonly little more than a tokenistic or pro forma gesture.

A rigorous 'rights-balancing' exercise as proposed, for example, by Alexy and Barak, imposes significant demands on a decision-maker. For example, a decision-maker must take into account complex factors including the intensity of an interference with rights, the importance of the objective sought to be achieved by an interference, and the relative importance of potentially competing rights. While, under EU law, 'rights-balancing' is an integral part of the proportionality principle, which must be applied by courts in determining whether or not to award a blocking injunction, there are significant problems with how the balancing exercise has been applied. To begin, even undertaking 'rightsbalancing' in the limited context of awarding a remedy requires some analysis of the relative weight to be given to potentially competing rights, such as copyright and freedom of expression. Yet, under EU law, there is no clarity concerning this

126 Geiger and Izyumenko, above n 44, 46, quoting Commission of the European Communities, 'Accompanying Document to the Proposal for a Council Framework Decision Amending Framework Decision 2002/475/JHA on Combating Terrorism: Impact Assessment' (Working Document No 1424, 6 November 2007) 29.

127 Orit Fischman Afori, 'Proportionality - A New Mega Standard in European Copyright Law' (2014) 46 International Review of Intellectual Property and Competition Law (IIC) 889; Angelopoulos, above n 41.

128 Alpana Roy and Althaf Marsoof, 'The Blocking Injunction: A Comparative and Critical Review of the EU, Singaporean and Australian Regimes' (2016) 38 European Intellectual Property Review 92, 95. 
fundamental issue: for example, on the one hand the InfoSoc Directive requires that copyright be given a 'high level' of protection ${ }^{129}$ while, on the other, in Rugby Football Union $v$ Consolidated Information Services Ltd (Formerly Viagogo Ltd) the UK Supreme Court endorsed the view that copyright and potentially competing privacy rights must be given equal precedence. ${ }^{130}$

One possible conclusion from applying 'rights-balancing' to internet blocking would be that the interference, both direct and systemic, with freedom of expression is so significant, and the potential benefits so slight, that any form of blocking to protect copyright would be disproportionate. Reaching such a conclusion would, however, be extraordinarily complex, not merely in weighing rights but also in matters relating to the importance of the objective of deterring copyright infringements, which would entail some assessment of the likelihood of the objective being achieved. The demands of engaging in such an analysis, together with the risks of arbitrariness and subjectivity, suggests that there is a case for caution and some deference to legislative decision-making. As explained in Parts IV and V of this article, the ECJ and UK courts have exercised a degree of deference in the 'rights-balancing' exercise, in effectively assuming that blocking injunctions can be proportionate, and focusing on whether particular injunctions do or do not disproportionality interfere with competing rights. That said, as further explained in Parts IV and V, the 'rights-balancing' engaged in by the ECJ and UK courts has been far from the sort of disciplined process proposed by those concerned to refute suggestions of arbitrariness, with the analysis tending to the superficial and perfunctory. It is difficult to disagree with the conclusion reached by Fontanelli, in the context of the ECJ applying 'rightsbalancing' in internet cases such as Scarlet Extended, that 'the Court either delegated proportionality to domestic courts or recited its elements as if it were a half-forgotten due diligence checklist'. ${ }^{131}$

Nevertheless, merely because a reasoning process is demanding, or its implementation flawed, does not mean that it is futile. Even within the limited scope given to the application of 'rights-balancing' by the ECJ and UK courts, the calibration of rights may set effective limits on the exercise of the court's discretion and on permissible awards. Thus, in Scarlet Extended, the ECJ drew a line by ruling that an injunction requiring generalised internet filtering was a disproportionate interference with rights. It would also seem that an award blocking access to a website hosting predominantly non-infringing content would likely fail a 'rights-balancing' exercise. A good test of whether 'rights-balancing' has any bite would be to ask whether a block that failed to prevent access to all but a very small minority of users would be disproportionate. It would, for example, seem difficult to imagine that a block that was completely ineffective

129 See Infopaq International A/S v Danske Dagblades Forening (C-5/08) [2009] ECR I-6569, I-6642 [40] (The Court).

130 [2012] 1 WLR 3333, 3346-7 [44]-[45], endorsing the proportionality analysis formulated by Arnold J in Golden Eye (International) Ltd v Telefónica UK Ltd [2012] RPC 698, 749 [117].

131 Filippo Fontanelli, 'The Mythology of Proportionality in Judgments of the Court of Justice of the European Union on Internet and Fundamental Rights' (2016) 36 Oxford Journal of Legal Studies 630, 652. 
could ever be other than a disproportionate interference with the rights of intermediary ISPs. This example, however, clearly illustrates how, in difficult cases, 'rights-balancing' proportionality can be subsumed by 'means/ends' analysis, as the justification for an interference with rights inevitably raises questions concerning the effectiveness of a measure that interferes with rights. The difficulties in applying 'rights-balancing' as anything other than a checklist, and the need to factor in the effectiveness of a blocking order, help to explain why the ECJ and UK courts have come to increasingly focus on 'means/ends' analysis, and especially on the effectiveness and costs of blocking orders.

Even given the limits of 'rights-balancing', however, there is a case to be made for greater use of this form of analysis under both UK and Australian law. For example, it is arguable that, especially in a jurisdiction that implicates fundamental rights, that 'rights-balancing' should be taken into account in statutory interpretation, including in resolving some of the ambiguities in the legislative conditions to establish jurisdiction identified in this article. ${ }^{132}$ Moreover, a disciplined form of 'rights-balancing' could both effectively constrain, and increase the transparency, of the exercise of the discretion to award an injunction. In relation to both decisions on jurisdiction and the exercise of the discretion, 'rights' analysis, however imprecise and flawed, has the advantage of ensuring that important considerations are taken into account.

\section{B Effectiveness of Blocking Injunctions and Orders}

As explained in this article, ${ }^{133}$ in the ECJ and UK courts, 'rights-balancing' has been increasingly subsumed by 'means/ends' analysis, with a focus on the effectiveness of blocking orders.

In practice, the main arguments against blocking injunctions, as a matter of policy and before the courts, have been that they are ineffective in that blocks can be easily circumvented and that they do not reduce the overall level of infringements. ${ }^{134}$ Arguments concerning effectiveness before the ECJ and UK courts have raised questions about what, in this context, is meant by 'effectiveness'? While in Telekabel, the ECJ adopted a 'reasonable effectiveness' standard, requiring only that an injunction make access difficult or seriously discourage users from accessing targeted sites, in the UK, Arnold J has held that an injunction can be proportionate even if it only prevents access by a minority of users. In Universal Music, on the other hand, Burley $\mathrm{J}$ accepted that to be effective an order must prevent a 'meaningful proportion' of Australian users from infringing copyright by accessing an offshore website.

Determining whether a measure, such as internet blocking, is effective is a complex task which first depends upon establishing criteria for assessing effectiveness. The low threshold for effectiveness under EU and UK law seems to have been set for two main reasons. First, no known form of blocking can be

\footnotetext{
132 See, eg, Michael Kirby, 'Statutory Interpretation: The Meaning of Meaning' (2011) 35 Melbourne University Law Review 113.

133 See Parts IV(A), V(C).

134 See Marsoof, above n 9, 651-5; Roy and Marsoof, above n 128, 99.
} 
absolutely effective in preventing access and, furthermore, measures such as generalised DPI filtering, which may be relatively more effective in preventing access, are likely to be overbroad and disproportionate. Secondly, as is clear from the judgments in Cartier, for example, the courts have displayed a consistent degree of deference to the legislature's decision to impose blocking obligations on intermediaries.

The reasoning supporting the low effectiveness threshold might be reconstructed as follows. The legislature has determined that blocking injunctions are an effective measure for protecting copyright. But blocking injunctions cannot be absolutely effective in preventing access to targeted websites. Determining whether an injunction is effective therefore cannot amount to an exercise in second-guessing the policy decision to impose an obligation on intermediaries, but must be directed at the narrower question of whether it deters access. Moreover, it is implicit from the UK judgments that targeted blocking should be seen as part of a broader set of strategies for addressing copyright infringements and, therefore, cannot be assessed by the impact of a particular injunction on the overall level of infringements. ${ }^{135} \mathrm{~A}$ sub-text to this argument is that online infringements, and the factors leading to infringements, are complex phenomena, such that it would be wrong to isolate one factor, such as a blocking order, and assume that this alone should bear the burden of reducing overall levels of infringement. Moreover, there are obviously problems in determining the effects of blocking orders before they have, individually or cumulatively, had a chance to work. Applying this reasoning, the effectiveness standard must therefore be whether an order has some effect on deterring access to targeted websites, and not on the overall level of infringement. That said, under EU and UK law, there remains room for debate concerning what amounts to 'seriously discouraging' users or where circumvention becomes so widespread that access is restricted to a small minority of users. Considerably less attention has been paid to the appropriate 'effectiveness threshold' by Australian courts, with Burley $\mathrm{J}$ in Universal Music accepting a submission by the applicant right holders, but with a lack of precision (or even argument) about the formulation and meaning of any proposed standard.

While the ECJ and UK courts have applied 'effectiveness' as a standard for determining whether or not to impose an order, there is scope for an effectiveness standard to be used in setting the terms of an order, potentially including mandating a particular blocking technique. The relationship between the effectiveness of a blocking technique and other considerations relating to proportionality have arisen before courts in the UK, but not as explicitly as could be the case. In Newzbin 2, in a separate judgment delivered considering the terms of a blocking order, ${ }^{136}$ Arnold J considered the terms of an order requiring BT to implement the Cleanfeed hybrid blocking system, concluding that it would be best to frame the injunction as requiring IP address re-routing (to the URL

\footnotetext{
135 The broader strategies include notice and takedown from domestic sites and platforms such as YouTube, as well as educational campaigns.

136 Twentieth Century Fox Film Corporation v British Telecommunication plc [No 2] [2012] 1 All ER 869.
} 
blocking) rather than IP address blocking, as the latter could be disproportionate in that it could result in over-blocking. ${ }^{137}$ In Dramatico Entertainment Ltd $v$ British Sky Broadcasting [No 2], however, Arnold J held that, as IP address blocking might prevent circumvention of Cleanfeed, it could be appropriate for this to be mandated, provided that the IP address was not shared with noninfringing websites. ${ }^{138}$

The position in the UK, where ISPs have put in place hybrid systems, such as Cleanfeed, can be compared with the position in Australia, where these general systems have not been deployed. In Roadshow [No 1], Nicholas J avoided prescribing a particular technique, requiring only that the ISPs 'take reasonable steps to disable access', which could be complied with by DNS blocking, IP address blocking or re-routing, URL blocking, or an alternative means agreed between the parties. ${ }^{139}$ In Universal Music, Burley J ordered the use of DNS blocking, while allowing the parties to agree on an alternative technique; ${ }^{140}$ but, as observed earlier, the judgment appeared to confuse DNS blocking and URL blocking. Reflecting what was proposed by the ISPs in the proceedings, ${ }^{141}$ the Australian ISPs have implemented the orders by applying DNS name blocking which, as explained in Part II, is relatively inexpensive, but is the least effective technique and the easiest to circumvent. ${ }^{142}$ This outcome illustrates the artificiality of attempts to separate out considerations relating to the effectiveness of access blocking in the abstract from the precise terms of an order, which may require assessment of the merits of blocking techniques.

If a court is to ensure that blocking orders are properly targeted, then some consideration of the implications of how an order is practically implemented is required. In this, the effectiveness of an order should be taken into account, even by courts that are not required to apply proportionality analysis to this issue. Needless to say, the proportionality of blocking techniques is necessarily related to the costs of implementing orders, and to the allocation of costs between right holders and intermediaries, which is considered in the next section of the article.

\section{Costs of Blocking Injunctions}

Between the parties, the costs of implementing blocking orders have been potentially the most contentious issue. If the costs of implementing an order are excessive relative to the effectiveness of blocking, then there can be no justification for blocking.

137 Ibid $872[6]$.

138 [2012] EWHC (Ch) 1152, [13].

139 Roadshow [No 1] (2016) 343 ALR 428, 462 orders 2-3.

140 Universal Music [2017] FCA 435, [81] order 2.

141 Roadshow [No 1] (2016) 248 FCR 178, 209 [148] (Nicholas J).

142 See Andy, First Aussie Pirate Bay Block Gets Defeated in Seconds (20 December 2016) Torrentfreak $<$ https://torrentfreak.com/first-aussie-pirate-bay-block-gets-defeated-in-seconds-161220/>; Paula Dootson, Kylie Pappalardo and Nicolas Suzor, 'Blocking Access to Illegal File-Sharing Websites Won't Stop Illegal Downloading' The Conversation (online), 15 December $2016<\mathrm{https}$ ://theconversation.com/ blocking-access-to-illegal-file-share-websites-wont-stop-illegal-downloading-70473>. 
In the UK, consideration of costs by the courts is conditioned by the extent to which capital costs of blocking infrastructure have already been incurred, such that the marginal costs of implementing an order are low. As explained above, ${ }^{143}$ in Cartier, the majority of the Court of Appeal upheld Arnold J's judgment concluding that the ISPs should bear the costs of complying with an order on the grounds that the legislature had determined that it was more efficient for a burden to be imposed on ISPs, that the ISPs made a profit from infringing services, and that they could pass on the costs to subscribers. In Roadshow [No 1], however, Nicholas $J$ held that, while intermediaries should bear the capital costs of establishing a blocking infrastructure, as this was a cost of carrying on business, he held that the right holders should be responsible for compliance costs, or a considerable proportion of them, as the intermediaries are innocent third parties and do not benefit commercially from copyright infringements. These conclusions were essentially adopted by Burley $\mathrm{J}$ in Universal Music, who added that 'the legislation most directly and immediately benefits copyright owners and exclusive licensees ...'. ${ }^{144}$

The costs, and the allocation of costs between right holders and intermediaries, associated with the implementation of blocking, may have significant implications for the use and effectiveness of a system for awarding blocking injunctions. For example, if compliance costs are borne by the right holders, as in the Australian applications, there may be less incentive to apply for injunctions, or to make applications supporting more costly forms of blocking, such as URL blocking. Given the importance of the issue, and how contentious it has been, the analysis of the issue by courts in the EU, UK and Australia has failed to throw much light on who should bear the costs. For instance, recourse to arguments that compliance costs are no more than the cost of doing business, or that costs should not be imposed on an innocent third party, do little more than beg the question.

If costs were subject to a rigorous form of proportionality analysis, however, the considerations relevant to the decision would become clearer. For example, if 'rights-balancing' analysis was to be applied, the impact of costs on the freedom of ISPs to conduct a business would be a highly relevant consideration. Applying 'means/ends' analysis, however, would raise considerations relating to whether it is more efficient to impose costs on intermediaries as least cost avoiders, or to internalise the negative externalities of providing unrestricted access to peer-topeer networks. ${ }^{145}$ As important as it is for proper limits to be set in relation to the conditions for establishing the court's jurisdiction, and in the exercise of the discretion to award an injunction, this may mean little if the form of the order, or the technique applied to block access, ends up being ineffective, or if the allocation of costs creates perverse incentives.

143 See Part V(B).

144 Universal Music [2017] FCA 435, [102].

145 Olivier Bomsel and Heritiana Ranaivoson, 'Decreasing Copyright Enforcement Costs: The Scope of a Graduated Response' (2009) 6(2) Review of Economic Research on Copyright Issues 13. 


\section{CONCLUSION}

A specific jurisdiction to award no-fault injunctions to block access to websites to prevent or deter copyright infringements has been introduced in the EU, UK, Singapore and Australia, and such awards have become a significant element in strategies pursued by copyright owners to combat online infringements. Blocking end-user access to the internet is, however, a controversial measure that raises significant public policy issues. This article claims that, as it is too early to assess the impact of blocking injunctions, either in isolation or as part of broader strategies to deter online copyright infringements, at this early stage it is more useful to focus on the scope for establishing principled limits on the jurisdiction to award blocking injunctions than to attempt to evaluate the overall effectiveness of blocking.

In summary, the article argues that it is important to establish limits on the jurisdiction to ensure that blocking does not unreasonably interfere with the rights of users, internet intermediaries and website operators, and that injunctions must at least have some degree of effectiveness. These considerations are expressly taken into account in the application of both aspects of the proportionality principle, namely 'rights-balancing' and 'means/ends' analysis, as implemented under EU law. While the ECJ and UK courts have applied the proportionality principle in judgments dealing with the jurisdiction to award blocking injunctions, there have been problems with how the principle has been applied. The problems include a lack of rigour in some of the proportionality analysis, and a failure to apply the principle to important issues, such as the interpretation of statutory conditions for establishing jurisdiction and the allocation of the costs of implementing blocking orders. Nevertheless, the EU and UK jurisprudence at least directs attention to the most important considerations in constraining the exercise of the jurisdiction, including the effectiveness of blocking orders. Due to a variety of considerations, however, including the high demands of proportionality analysis, and the risks of arbitrariness and subjectivity, EU and UK courts have deferred to the legislature in so far as accepting that a jurisdiction to award blocking orders, as established under article 8(3) of the InfoSoc Directive, is proportionate. This deference has significantly influenced the proportionality analysis leading, for example, to the ECJ and UK courts adopting a low threshold for evaluating the effectiveness of an order and, in the process, effectively defining the objective of the jurisdiction as deterring access to particular target websites, rather than reducing overall levels of online infringements.

Although the jurisdiction under section 115A of the Australian Act is confined to orders blocking access to offshore locations, it appears relatively easy for jurisdiction to be established under the Australian provision and, once established, the Federal Court seems to have a broader discretion than courts in either the UK or Singapore. While Australian courts are not bound by the proportionality principle, there seems considerable scope for the law to develop so that considerations relevant to proportionality analysis are taken into account in setting limits to the exercise of the Australian jurisdiction. First, as the 
proportionality of an order is specifically mentioned as one of many discretionary factors in section 115A(5) of the Act, there is potential for the Court to interpret this as imposing both 'rights-based' and 'means/ends' constraints as part of the balancing exercise. Secondly, given ambiguities and weaknesses in the drafting of section 115A, it is open for considerations relevant to proportionality, and especially those relating to the balance between relevant rights, to be taken into account in statutory interpretation. Thirdly, more express attention could be given to considerations such as effectiveness in setting court orders, including in relation to the relative effectiveness of blocking techniques and the allocation of the costs of implementing orders.

Proportionality analysis is demanding and ambitious. Nevertheless, the introduction of some form of proportionality has the potential to improve, first, the nature and transparency of judicial decision-making in awarding a blocking injunction and, secondly, impose principled limits on the jurisdiction. Given the controversial nature of the jurisdiction, a more structured and rigorous form of analysis - incorporating not only 'means/ends' analysis, but also 'rightsbalancing' - would assist in establishing its legitimacy, but also in preventing the exercise of the jurisdiction being reduced to a pro forma exercise. 